\title{
English summaries
}

\author{
Historian, Crisis and State
}

A. GUERY

For the first time in modern history, less State is considered to be the solution to crisis. At the same time, it became the main question in French history. This interest for the State seems to be the death certificate of the early modern and modern form of central power, in a country where the history of State was associated with the formation of the Nation. But is the State actually an outdated form of power?

Naples, 1610: How may One be an Officer?

M. Peytavin

During the sixteenth and seventeenth centuries, Neapolitans are subjects of the King of Spain. The project of suppressing a tribunal (the Zecca) revealed most things about the world of the office: it obeys the imperatives of economic factors, its boundaries are blurry, and there are many ways to transgress them; some remain at its borders, while others are outside entirely; it has much to do with the rules of feudal society; the channels that provide the financial transactions to sustain this system are identifiable; this is not a site of enrichment, but rather one of gift and counter-gift; it is a source of income; it is, in the end, a multifaceted reality. The traditional oppositions: office-notability, office-feudalism, should be reconsidered in light of the behaviors adopted, the language utilized and the strategies developed at the moment of access to the office. The social history of institutions requires the examination of the office, an Ancien Régime institution if ever there was one. The office shows itself as much more than the support system that evolved to sustain venality. There remains much for us to learn about the functioning of societies in the modern era.

\section{Royal and Seigneurial Patronage Networks towards the End of the Old Regime. Case-Studies on Spain}

C. WINDLER

Instead of focusing, in a centralist perspective, on the institutional aspects of State formation, this paper turns the attention towards the complex set of interactions between institutions and patronage networks in the relations between the Crown, the royal tribunals and administrations, the seigneurial aristocracy and the local elites. From the 18th century political changes implied a profound restructuring of the patronage networks of both the seigneurial aristocracy and the Crown. Influential local notables not only adapted dynamically to changing political conditions, but contributed themselves to shape them. The crisis of the Old Regime and the esta- 


\section{ENGLISH SUMMARIES}

blishment of a liberal political order consecrated their power over the formal state structures. The paper concludes that their way of reorganizing patronage network.s was not the characteristic of an archaic rural world, but, on the contrary, an efficient and rational strategy to participate in the political transformations.

\section{Dismantling the Patrimony: Women and Property in Medieval Marseille}

D. L. SMAII.

The dowry in medieval Europe has long been understood to be one of the key provisions in a set of statutory regulations that conspired to disinherit daughter: and preserve patrimonies within males lines of descent. Evidence from mid-fourteenth-century Marseille reveals that despite these legal norms, daughters at all social levels frequently enjoyed considerable rights in parental estates, although the coming of the plague appears to have generated new disinheriting strategies among the patriciate. Since much inherited wealth flowed through women's hands, familial properties were typically reformed in every generation out of the husband's and th' wife's estates. Since husbands typically managed the joint estate, the principle that the wife was by virtue of her dowry the first creditor of an insolvent husband could even be used as a legal shelter in case of bankruptcy. Here, the dowry was serving as a tool not of disinheritance but rather of preservation.

\section{Family Practices, Law and the Construction of Differences (15th-19th centuries)}

B. Deroue'?

Should one look to the regional diversity in private law under the Old Regime to explain the variety of family practices in France during this period? These two forms of diversity, however, cannot be entirely superimposed, nor do they correspond term for term. In reality, the difference between law and social practices cannot simply be understood in terms of respect for or transgression of specific norms, but in terms of the categories which the law uses to formalize these practices, make sense of them and confer upon them a certain legitimacy. Several examples show that certain kinds of law, with the same basic principles, were able to serve in cases of strikingly different family practices. The relationship between these two levels is less a problem of direct reflexion or influence but that of translation. 